\title{
EFEKTIVITAS PELATIHAN HIDROPONIK UNTUK MENINGKATKAN RAGAM KOMPETENSI GURU KETERAMPILAN DI SEKOLAH LUAR BIASA
}

\author{
Subagya, Arsy Anggrellanggi, Munawir Yusuf, Ravik Karsidi, Erma Kumala Sari, \\ Priyono \\ Pendidikan Luar Biasa, Universitas Sebelas Maret, Surakarta \\ Arsy@staff.uns.ac.id,
}

\begin{abstract}
Abstrak
Penelitian ini bertujuan untuk mengetahui efektivitas pelatihan hidroponik secara maya guna meningkatkan keterampilan guru-guru dan kepala SLB di Jawa Tengah dalam pelaksanaan pengajaran keterampilan hidroponik siswa SLB. Jenis penelitian ini adalah penelitian eksperimen, desain penelitian yang digunakan dalam penelitian ini adalah One-Group PretestPosttest Design. Populasi dalam penelitian ini adalah seluruh guru dan kepala SLB di Jawa Tengah. Pengambilan sampel dilakukan dengan teknik purposive sampling yang berjumlah 85 guru SLB di Jawa Tengah. Pengumpulan data penelitian menggunakan kuisioner melalui google form. Teknik analisis data menggunakan uji t. Hasil penelitian menunjukkan bahwa nilai rata-rata pretest adalah 22,67 dan nilai rata-rata posttest adalah 32,99, hal ini berarti hasil pelatihan mengalami peningkatan sebesar 10,318. Hasil uji t menunjukkan bahwa pelatihan hidroponik secara signifikan $(0,00)$ efektif meningkatkan kompetensi guru keterampilan SLB di Jawa Tengah. Berdasarkan paparan di atas, dengan pelatihan hidroponik secara maya dapat meningkatkan kompetensi guru keterampilan SLB di Jawa Tengah.
\end{abstract}

Kata Kunci : Pelatihan, Hidroponik, Keterampilan, Guru

\section{PENDAHULUAN}

Vocational skills dapat juga disebut dengan keterampilan kerja atau kecakapan vokasional. Keterampilan vokasional merupakan bagian dari konsep keterampilan hidup (life skills) dalam sistem persekolahan (Anwar dalam Dewi, 2017). Kecakapan vokasional berkaitan dengan bidang pekerjaan yang terdapat di masyarakat dan lebih memerlukan keterampilan motorik yang mencakup kecakapan vokasional dasar atau pravokasional yang terdiri dari kecakapan menggunakan alat kerja, alat ukur, memilih bahan, merancang produk; dan kecakapan vokasional penunjang (Supriatna, 2007). keterampilan vokasional juga berguna untuk memperoleh dan mengembangkan pekerjaan dan profesi supaya memperoleh kompensasi finansial dan status yang layak (Ahmad, 2013). Selain itu, secara substansial vocational skills merupakan salah satu kemampuan profesional anak didik dalam membangun komitmen untuk bisa terampil dalam bidang tertentu (Ilahi, 2012). Kurikulum di SMALB saat ini terdiri dari 70\% vokasi atau 26 jam pelajaran, dan tiap siswa diberi keleluasaan untuk memilih dua vokasi. Kenyataan di lapangan, pemilihan vokasi tidak berdasarkan atas minat siswa, tapi berdasar kompetensi guru di sekolah lebih dari 80\% guru SMALB merupakan lulusan Pendidikan Luar Biasa (PLB) yang tidak mempunyai latar belakang pendidikan vokasi 
sehingga masih minim memiliki keterampilan vokasional. Dengan demikian, pelatihan vokasional untuk meningkatkan kompetensi keterampilan vokasional guru sangat diperlukan karena keterampilan vokasional sangat penting untuk menunjang masa depan anak. Salah satu keterampilan vokasional yang dapat diajarkan kepada siswa adalah keterampilan vokasional dalam bidang pertanian yaitu pelatihan hidroponik.

Pelatihan menurut Simamora (2006) menjelaskan bahwa pelatihan (training) merupakan proses pembelajaran yang melibatkan perolehan keahlian, konsep, pengaturan, atau sikap untuk meningkatkan kinerja tenaga kerja. Terdapat unsur dalam proses pelaksanaan pelatihan yang meliputi peserta pelatihan, pelatih, waktu pelatihan, bahan latihan, bentuk pelatihan (Hamalik, 2007).

Perkembangan dalam bidang pertanian sangat pesat dari tahun ke tahun. Salah satu teknologi pertanian yang sedang marak disebarluaskan adalah teknologi hidroponik yaitu sebuah teknologi yang muncul karena langkanya lahan pertanian (Putra dkk, 2018). Hidroponik adalah cara bercocok tanam yang tidak menggunakan media tanah serta dapat memanfaatkan lahan- lahan yang sempit atau kurang produktif, seperti lahan pekarangan rumah (Pascual, 2018). Selain itu, menurut Izzuddin (2016) hidroponik adalah suatu metode bercocok tanam tanpa menggunakan media tanah, melainkan dengan menggunakan larutan mineral bernutrisi atau bahan lainnya yang mengandung unsur hara seperti sabut kelapa, serat mineral, pasir, pecahan batu bata, serbuk kayu, dan lain-lain sebagai pengganti media tanah. Selain dalam tekniknya, teknologi hidroponik memiliki perawatan yang sangat mudah, karena tumbuhan, tanaman atau sayuran dapat tumbuh dengan mudah tanpa menggunakan tanah, hanya dengan talang air, botol kemasan yang sudah tidak terpakai dan juga bisa memanfaatkan barang-barang yang sudah tidak diperlukan seperti ember, baskom dan sebagainya (Satya dkk, 2017).

Pelatihan hirpononik dapat dijadikan media untuk terapi bagi anak dengan hambatan intelektual dan terbuksi secara signifikan dapat meningkatkan aspek neuromaskuler, tetapi tidak signifikan dalam membangkitkan motivasi terhadap pilihan vokasi mereka (Job, B.S, 2012).

Hidroponik juga dapat meningkatkan secara signifikan dalam skor pengetahuan lingkungan serta skor keseluruhan yang lebih tinggi pada pelestarian lingkungan, dan dalam beberapa kasus, komitmen untuk mempraktikkan perilaku prolingkungan. Temuan tak terduga ditemukan dalam kaitannya dengan sejauh mana siswa dengan hambatan intelektual unggul dalam desain pedagogis (Scheneler, A,J., dkk, 2015) 
Berdasarkan uraian di atas menjelaskan bahwa guru SLB memerlukan pelatihan keterampilan vokasional. Salah satu pelatihan keterampilan vokasional yang dilakukan adalah pelatihan hidropronik yang diharapkan dapat meningkatkan ragam kompetensi guru keterampilan. Dengan demikian, peneliti melakukan pelatihan hidroponik kepada guru SLB untuk mengetahui sejauh mana efektivitas pelatihan hidroponik terhadap ragam kompetensi guru keterampilan di SLB.

\section{METODE}

Jenis penelitian ini adalah eksperimen, desain penelitian yang digunakan Pre-Experimental Design dengan model desain One-Group Pretest-Posttest Design. Populasi dalam penelitian ini adalah seluruh guru dan kepala SLB di Jawa Tengah. Pengambilan sampel dilakukan dengan teknik purposive sampling berjumlah 85 guru SLB di Jawa Tengah. Pengumpulan data menggunakan kuisioner yang dilakukan melalui media google form.. Teknik analisis data menggunakan uji t.

\section{HASIL DAN PEMBAHASAN}

Berdasarkan dari uji t yang telah dilakukan dari skor peserta sebelum diberikan pelatihan dan setelah diberikan pelatihan (skor pre dan posttest) berikut di peroleh hasil:
Tabel 1. Analisis skor pre dan post

\begin{tabular}{|c|c|r|r|r|r|}
\multicolumn{2}{|c|}{} & Maired Samples Statistics \\
\hline \multicolumn{2}{|c|}{} & Mean & N & $\begin{array}{c}\text { Std. } \\
\text { Deviation }\end{array}$ & $\begin{array}{c}\text { Std. Error } \\
\text { Mean }\end{array}$ \\
\hline \multirow{2}{*}{ Pair 1 pretest } & 226.706 & 85 & 679.529 & .73705 \\
\cline { 2 - 7 } & posttest & 329.882 & 85 & 580.741 & .62990 \\
\hline
\end{tabular}

Berdasarkan dari tabel 1 . diperoleh mean dari skor pretest adalah 22,67 dari 85 peserta pelatihan dan mean dari skor posttest adalah 32,99. Dengan demikian, terjadi peningkatan antara nilai pre dan posttest yaitu sebesar 103,2 (45,5\%).

Tabel 2. Analisis efektivitas pelatihan hidroponik

\begin{tabular}{|c|c|c|c|c|c|c|c|c|c|}
\hline \multicolumn{10}{|c|}{ Paired Samples Test } \\
\hline & & \multicolumn{5}{|c|}{ Paired Differences } & \multirow{3}{*}{$t$} & \multirow{3}{*}{$d f$} & \multirow{3}{*}{$\begin{array}{l}\text { Sig. (2 } \\
\text { tailed) }\end{array}$} \\
\hline & & \multirow[t]{2}{*}{ Mean } & \multirow[t]{2}{*}{$\begin{array}{c}\text { Std. } \\
\text { Deviation }\end{array}$} & \multirow[t]{2}{*}{$\begin{array}{c}\text { Std. Error } \\
\text { Mean }\end{array}$} & \multicolumn{2}{|c|}{$\begin{array}{l}95 \% \text { Confidence } \\
\text { Interval of the } \\
\text { Difference }\end{array}$} & & & \\
\hline & & & & & Lower & Upper & & & \\
\hline Pair 1 & $\begin{array}{l}\text { pretest - } \\
\text { posttest }\end{array}$ & -1.031 .765 & 739.886 & .80252 & -1.191 .354 & -872.175 & -12.857 & 84 & .000 \\
\hline
\end{tabular}

Berdasarkan dari analisis tabel 2. diperoleh mean dari hasil pre dan posttest adalah 103,2 dengan t hitung 12, 857 (sig 0,00), berarti pelatihan tersebut secara signifikan efektif untuk meningkatkan kompetensi guru keterampilan di SLB Jawa Tengah.

Hasil tersebut di atas sejalan dengan penelitian yang telah dilakukan oleh Sarno (2018) menyatakan bahwa hasil kegiatan pelatihan hidroponik membawa implikasi pada peningkatan pengetahuan dan kapasitas serta keterampilan masyarakat dalam mengembangkan teknologi hidroponik sayuran secara organik yang ramah lingkungan. Selain itu, penelitian yang dilakukan oleh Sardanto (2017) menyatakan bahwa pelatihan hidroponik dapat meningkatkan pengetahuan warga tentang pentingnya 
pemanfaatan lahan pekarangan dengan sistem bercocok tanam hidroponik, sehingga memberikan kesempatan kepada mereka untuk menjadi wirausaha baru yang kedepannya akan tergabung dalam kelompok-kelompok usaha. Penelitian yang dilakukan oleh Malau dkk (2018) memperoleh hasil yang meliputi warga suda mampu dan memahami tanaman apa saja yang dapat ditanam dengan metode hidroponik, warga sudah memahami bagaimana perencanaan biaya bercocok tanam dengan mengunakan metode hidroponik, warga memahami alat-alat apa saja yang digunakan dalam bercocok tanama hidroponik,warga dapat melatih warga lain dalam bercocok tanam dengan menggunakan metode Hidroponik.

Berdasarkan dari hasil penelitian dan pembahasan dapat disimpulkan bahwa pelatihan hidroponik mampu meningkatkan ragam kompetensi guru keterampilan karena pelatihan hidroponik mampu meningkatkan pengetahuan guru tentang manfaat dari metode penanaman hidroponik, mengembangkan potensi guru untuk memakai metode hidroponik sayuran secara organik yang ramah lingkungan serta mampu melatih guru untuk menstransfer ilmu kepada siswa di kelas.

\section{SIMPULAN}

Berdasarkan dari hasil penelitian dan pembahasan dapat disimpulkan bahwa pelatihan hidroponik untuk meningkatkan ragam kompetensi guru keterampilan di SLB cukup efektif. Pelatihan hidroponik mampu meningkatkan berbagai keterampilan guru yang meliputi:
1. Meningkatkan pengetahuan guru tentang manfaat dari metode penanaman hidroponik,

2. Mengembangkan potensi guru untuk memakai metode hidroponik sayuran secara organik yang ramah lingkungan.

3. Melatih guru untuk menstransfer ilmu kepada siswa di kelas.

\section{SARAN}

Pelatihan hidroponik yang telah diajarkan kepada gur siswa di SLB masing-masing untuk meningkatkan keterampilan vokasional siswa.

\section{Ucapan terima kasih atas kerjasam} yang baik kepada:

1. Ketua MKKS SLB Jawa Tengah

2. Ketua IGPKhI Jawa Tengah

3. PT. Dalzon Chemical Indonesia, Di Malang

4. APPKhI Pusat

5. PSD-LPPM UNS

\section{DAFTAR PUSTAKA}

Dewi, D. P. (2017).Keterampilan Vokasional Dengan Hambatan Intelektual (Vocational Skills as Preparations In the World Oo Work For Children With Intellectual Disabilities). Vol 7, 231-238

Hakimah, dkk. (2017). Pemberdayaan Masyarakat Melalui Pelatihan Hidroponik Membentuk Wirausahawan Baru Pada Perum Kuwak Utara 
Kelurahan Ngadirejo Kota Kediri. Jurnal Pengabdian Masyarakat: Adinnus Vol. 1 No. 1 (2017): Volume 1 Nomor 1 Tahun 2017

Hamalik, O. (2007). Manajemen Pelatihan Ketenagakerjaan Pendekatan Terpadu Pengembangan Sumber Daya Manusia. Jakarta: Bumi Aksara

Illahi, Takdir, M, (2012). Pembelajaran Discovery Strategy dan Mental Vocational Skill. Jogjakarta: Diva Press.

Izzuddin, A. (2016). Wirausaha Santri Berbasis Budidaya Tanaman Hidroponik.Jurnal Pengabdian Masyarakat/DIMAS, 12(2), 351-366.

Job, B.S. (2012). Improving Work Adjustment Skills in Students with Mental Retardation Using Hydroponics Program. Korean Journal of Horticultural Science and Technology. Dapat diunduh pada: https://agris.fao.org/agrissearch/search.do?recordID=KR20 15005871

Pascual M. P, Lorenzo, G, A., Gabriel, A.G.. (2018). Vertical Farming Using Hydroponic System. Towrd a Sustainable Onion Production in Nueva Ecija, Philippines.

Putra, E.S., Jamaludin, J, dan Djatmiko D. (2018). Comparation of hydroponic system design for rural communities in Indonesia. J. Arts Humanit. 7(9):14-21.

Satya, T.M, Tejaningrum, A., \& Hanifah. (2017). Manajemen
Usaha Budidaya Hidroponik. Jurnal Dharma Bhakti Ekuitas, 1(2), 53-57

Schneller, J.A (2015). A Case Study of Indoor Garden-Based Learning With Hydroponics and Aquaponics: Evaluating ProEnvironmental Knowledge, Perception, and Behavior Change. Journal Applied Environmental Education \& Communication. Volume 14, 2015 - Issue 4. Dapat diunduh pada:

https://www.tandfonline.com/d oi/abs/10.1080/1533015X.2015 .1109487 ?scroll=top\&needAcc ess=true\&journalCode=ueec20

Simamora, H.. (2006). Manajemen Sumber Daya Manusia, Edisi 2. Yogyakarta: STIE YKPN.

Supriatna, M. (2007). Konsep Pendidikan Berorientasi Kecakapan Hidup di Sekolah Menengah Pertama. Jakarta: Depdiknas.

Susanto, A. (2013). Teori Belajar dan Pembelajaran di Sekolah Dasar. Jakarta: Kencana Prenada Media Group 